\title{
Morphophysiological characterization of leaves and inflorescences of commercial mini chrysanthemum varieties
}

\author{
Carolina Rodrigues Victor de Carvalho ${ }^{1}$, Mirelle Nayana de Sousa Santos ${ }^{2 *}$, Ana Maria Mapeli ${ }^{1}$
}

\begin{abstract}
Chrysanthemum is among the oldest plants cultivated by man, being widely cultivated in Brazil. In view of its economic importance and use in breeding, the present study aims to characterize mini chrysanthemum varieties, focusing on morphological and physiological parameters. Therefore, four varieties of mini chrysanthemums, in pots, were acquired in the local market: V1 - 'Swifty Light Pink' (purple), V2 - 'Diablo Time' (red), V3 - 'White Cherie' (white); V4 - 'Giovanni' (yellow), from which they were taken leaves and inflorescences samples for measurement of height, diameter and fresh mass, as well as to quantify the total soluble sugar (TSS, \%), reducing sugar (RS, \%), non-reducing sugar (NRS, \%), anthocyanin and chlorophyll contents. Regarding the characterization of inflorescences, it was found that 'Diablo Time' had the largest diameter, height and fresh weight, in these last two cases not differing from 'Giovanni', which had lower anthocyanin content; while the highest values of carbohydrate content were found in 'White Cherie'. In relation to the characterization of the leaves, 'Giovanni' had the largest dimensions, fresh mass and chlorophyll content. Already 'Swifty Light Pink' stood as to the sugar contents. Thus, it is clear that there are morphophysiological differences between the chrysanthemum mini varieties, which can contribute to breeding programs.
\end{abstract}

Keywords: Dendranthema grandiflorum, physical characteristics, plant pigments, non-structural carbohydrate content.

\section{Resumo}

Caracterização morfofisiológica de folhas e inflorescências de variedades comerciais de minicrisântemo O crisântemo faz parte do conjunto de plantas mais antigas a serem cultivadas pelo homem, possuindo grande área de produção de flores no Brasil. Diante de sua importância econômica e uso em melhoramento genético, o presente trabalho tem como objetivo caracterizar variedades de minicrisântemos, com ênfase em parâmetros morfológicos e fisiológicos. Para tanto, foram adquiridas no comércio local, quatro variedades de minicrisântemos em vaso: V1 - 'Swifty Light Pink' (lilás), V2 - 'Diablo Time' (vermelho), V3 - 'White Cherie' (branco); V4 - 'Giovanni' (amarelo), das quais foram retiradas amostras de folhas e inflorescências para a mensuração de altura; diâmetro; massa fresca, bem como quantificação do teor de açúcares solúveis totais (AST\%), açúcares redutores (AR\%) e açúcares não redutores (ANR\%); teor de antocianina e clorofila. Quanto à caracterização das inflorescências, constatou-se que a 'Diablo Time' apresentou o maior diâmetro, altura e massa fresca, nestes dois últimos casos não diferindo de 'Giovanni', que apresentaram menor teor de antocianina; enquanto que os maiores valores de teor de carboidrato foram verificados em 'White Cherie'. No que se refere à caracterização das folhas, 'Giovanni' apresentou as maiores dimensões, massa fresca e teor de clorofila. Enquanto 'Swifty Light Pink' se destacou quanto aos teores de açúcares. Assim, percebe-se que há diferenças morfofisiológicas entre as variedades de minicrisântemo, o que pode contribuir em programas de melhoramento genético.

Palavras-chave: Dendranthema grandiflorum, características físicas, pigmentos vegetais, teor de carboidrato não estrutural.

\footnotetext{
${ }^{1}$ Universidade Federal do Oeste da Bahia, Centro de Biologia e Ciências da Saúde, Barreiras-BA, Brazil.

${ }^{2}$ Universidade Federal de Viçosa, Departamento de Biologia de Plantas, Viçosa-MG, Brazil. *Corresponding author: mirellebio@hotmail.com
} 


\section{Introduction}

The ornamental plant sector is under continuous expansion in Brazil due to several factors, such as improvements in market structure, growing purchasing power of producers and consumers, diversification of species and dissemination of new production technologies (Zandonadi et al., 2018). As such, it is one of the most promising segments of horticulture and agribusiness. According to data from the Brazilian Institute of Floriculture (Ibraflor, 2019), approximately 8248 flower products are available in Brazil, originating from a total cultivated area of 14992 ha. In this scenario, despite the 2018 crisis, the sector recorded a $7 \%$ increase in domestic sales compared to the year 2017 .

The chrysanthemum (Dendranthema grandiflorum Ramat.) is one of the most popular plants in Brazil due of its diverse colors and exuberant inflorescences. According Brainer (2018) chrysanthemum is among the most widely cultivated flower species in Brazil. Chrysanthemums are herbaceous, perennial plants, grown as annual plants, with simple leaves and inflorescence, called chapter, consisting, in general, of two types of flowers: ligulate and tubular flowers. Ligulate flowers are usually distributed on the periphery of the inflorescence and are unisexual female or even sterile, while tubular flowers are concentrated in the center and are hermaphroditic (Barbosa et al., 2019).

Currently, the mini chrysanthemum stands out, which presents from $0.5 \mathrm{~m}$ to $1.0 \mathrm{~m}$ high, small inflorescences with different shapes and colors of flowers, vase life of 3 to 4 weeks and availability throughout the year (Veiling Holambra, 2020). In the market, about 17 mini chrysanthemums varieties are available, distributed in the mini daisy and mini sunflower types (Terra Viva, 2020). Considering the use as a cut flower can be used mini daisies ['Rejumbo' (yellow), 'Desmond' (white), 'Framint' (white), mini (white), 'Refury' (bronze), 'Moon Light' (pink) and 'Chat' (lilac)] or mini sunflower ['Calimero Pink (pink), 'Calimero Orange' (orange), 'Calimero Snow' (white and yellow) and 'Calimero Sunny' (yellow)] while the main varieties of mini daisies used for pot production are 'Giovanni' (yellow), 'Honey Cherie' (yellow), 'White Cherie' (white), 'Champagne Cherie' (champagne), 'Lemon Cherie' (lemon), 'Sumo Time' (pink), 'Diablo Time' (red) and 'Regina' (red) (Barbosa et al., 2019). In the scientific literature, there is a lack of studies with mini chrysanthemums, being an interesting line of research due to the popularization of ornamental plants.

Considering the importance of identifying varieties since the early stages of development, it becomes relevant to carry out morphological characterization studies, which allows identification even when there are no flowers and/ or fruits. In addition, the determination of morphological parameters of varieties is one of the stages of certification programs, breeding and germplasm conservation.

In the current scenario, it is necessary to develop new hybrids, due to consumer demand and innovations in the floristic sector. Thus, studies involving species morphology and physiology become of great value, since these information's are the basis for plant breeding programs, focusing mainly on the appearance and durability of flowers (Boutigny et al., 2020).

When selecting ornamental plants, the consumer considers the color of the leaves and flowers, which is a consequence of the amount of vegetable pigments. Chlorophyll is responsible for the greening of the leaves, being degraded at the beginning of senescence, so that yellowing is one of the first symptoms of this physiological stage (Taiz et al., 2017). In flowers, the main chromophoric agents are flavonoids, such as anthocyanins that are responsible for the pink, orange, red, violet and blue coloration of most flowers (Brouillard, 1988), as well as attracting pollinators and dispensers and protection of the plant against ultraviolet rays and antimicrobial agents (Lopes et al., 2007, Park et al., 2015).

Other relevant characteristics at the time of purchase of ornamental plants refer to the floral openness and durability, which is directly related to sucrose concentration, as it improves water absorption, stimulates the opening of flowers and it is a respiratory substrate, ensuring energy production and maintenance of vital processes. This carbohydrate is the result of photosynthesis, key process for plant development, because it is responsible for the accumulation of all organic matter in plants. In this context, chlorophylls stand out, essential pigments for the absorption of light, initiating the photochemical phase of the photosynthetic process (Taiz et al., 2017).

The varying quality of chrysanthemums has been related to the most diverse problems, such as leaf yellowing (Satoh et al., 2008), leaf wilting (Van Doorn and Cruz, 2000) and flower wilting (Adachi et al., 2000). These data reinforce the importance of information about the physiological cycles of the many existing varieties, which may be useful for breeding programs, with a view to meeting the demands of consumers, who are looking for innovations.

Considering the economic importance of chrysanthemums and the need for more in-depth investigations the present study aims to characterize mini chrysanthemum varieties, focusing on morphological and physiological parameters.

\section{Material and Methods}

The mini chrysanthemum plants used in this experiment were acquired in the local market, being coming from Holambra-SP. All pots were at the desirable point of sale, considering 90\% uniformity in height, plant diameter, number of open flowers and point of opening (Veiling Holambra, 2019). The pots exhibited good support, lack of pest/diseases and $50 \%$ of the flower area open.

The experimental materials consisted of four minichrysanthemum varieties V1 - 'Swifty Light Pink' (lilac), V2 - 'Diablo Time' (red), V3 - 'White Cherie' (white); V4 - 'Giovanni' (yellow). Five inflorescences and 10 leaves were taken from each specimen to determine the preestablished parameters.

To examine the quality of the potted plants, morphophysiological evaluations were carried out on 
the inflorescences and leaves, since both organs directly interfere in appearance. Therefore, the morphological aspects (height and diameter) were measured using a digital pachymeter and fresh mass was determined by weighing on an analytical balance. Physiological aspects were also measured, including the total leaf chlorophyll content, which was determined using portable chlorophyll meter (Minolta-SPAD 502R ${ }^{\circledR}$ ) considering three different points in the middle region of the leaf blade. Besides that, the anthocyanin content of the flowers was determined following the method of Fuleki and Francis (1968), with readings taken by a spectrophotometer at $535 \mathrm{~nm}$. The concentration of anthocyanin pigments was calculated based on the extract volume and mass of the sample, from pelargonidin-3-glucoside, and the molar absorptivity coefficient of 19780 .

In the analysis of the non-structural carbohydrates in the inflorescence and leaves of mini chrysanthemums, the total soluble sugar (TSS) contents were quantified by the phenol-sulfuric acid method (Dubois et al., 1956); reducing sugars (RS) were determined by the Nelson-Somogy method (Nelson, 1944); and non-reducing sugars (NRS) were estimated by subtracting RS from TSS.

The experiment was set up as a completely randomized design with five replicates. The experimental unit consisted of five inflorescences and 10 leaves. Data were interpreted by analysis of variance, with means compared by the ScottKnott test at the 5\% probability level, using the SISVAR statistical program 5.6 (Ferreira, 2011).

\section{Results and Discussion}

The morphological characteristics of the inflorescences, fresh mass and anthocyanin content of the four mini chrysanthemum varieties in this study differed significantly (Table 1). 'Diablo Time' and 'Giovanni' presented similar results for diameter, with a difference of approximately $4.21 \mathrm{~mm}$ compared to 'Swifty Light Pink' and 'White Cherie'. 'Diablo Time' also showed the greatest height values, which were approximately $32.42 \%$ higher than that found on 'Swifty Light Pink' and 16.56\% higher than that of 'White Cherie' (Table 1).

Table 1. Morphophysiological characterization of inflorescences and leaves of four mini chrysanthemum varieties.

\begin{tabular}{|c|c|c|c|c|}
\hline \multicolumn{5}{|c|}{ Inflorescences } \\
\hline Variety & Diameter (mm) & Height (mm) & Fresh mass (g) & $\begin{array}{l}\text { Anthocyanin } \\
\left(\mathrm{mg} 100 \mathrm{~g}^{-1}\right)\end{array}$ \\
\hline 'Swifty Light' 'Pink' & $9.34 \mathrm{~b}$ & $30.17 \mathrm{c}$ & $2.69 \mathrm{~b}$ & $1.02 \mathrm{a}$ \\
\hline 'Diablo Time' & $12.97 \mathrm{a}$ & $39.95 \mathrm{a}$ & $4.04 \mathrm{a}$ & $0.84 \mathrm{a}$ \\
\hline 'White Cherie' & $8.76 \mathrm{~b}$ & $33.69 \mathrm{~b}$ & $1.84 \mathrm{c}$ & $0.85 \mathrm{a}$ \\
\hline 'Giovanni' & $12.18 \mathrm{a}$ & $34.86 \mathrm{~b}$ & $3.78 \mathrm{a}$ & $0.26 \mathrm{~b}$ \\
\hline \multicolumn{5}{|c|}{ Leaves } \\
\hline Variety & Diameter (mm) & Height (mm) & Fresh mass (g) & Chlorophyll (\%) \\
\hline 'Swifty Light Pink' & $18.68 \mathrm{c}$ & $40.40 \mathrm{~b}$ & $1.77 \mathrm{~b}$ & $31.70 \mathrm{c}$ \\
\hline 'Diablo Time' & $21.57 \mathrm{~b}$ & $42.36 \mathrm{~b}$ & $1.45 \mathrm{~b}$ & $36.00 \mathrm{~b}$ \\
\hline 'White Cherie' & $24.35 \mathrm{a}$ & $47.32 \mathrm{a}$ & $1.67 \mathrm{~b}$ & $40.42 \mathrm{a}$ \\
\hline 'Giovanni' & $25.73 \mathrm{a}$ & $49.70 \mathrm{a}$ & $2.57 \mathrm{a}$ & $42.82 \mathrm{a}$ \\
\hline
\end{tabular}

Means followed by the same letter do not differ according to the Scott-Knott test at the 5\% probability level.

The flowers of 'Swifty Light Pink', 'Diablo Time' and 'White Cherie' stood out with 3.5 times more anthocyanin pigment than 'Giovanni'. Park et al. (2015) evaluated the anthocyanin content of 23 cultivars of chrysanthemum and observed that those with bright red and violet bracts contained high levels of anthocyanin, unlike white varieties, which did not exhibit observable levels. This may be because anthocyanin, a strong soluble pigment, affects mainly the development of orangish-to-red and purple-toblue flowers.

The inflorescences of 'Diablo Time' and 'Giovanni' contained 1.5 and 2.2 times fresher matter than varieties 'Swifty Light Pink' and 'White Cherie', respectively (Table 1). Additionally, variety 'Swifty Light Pink' also obtained a higher fresh weight than 'White Cherie'. It is known that fresh mass refers to the content of water 
and matter. Thus, it appears that there may be variable characteristics of turgescence and carbohydrate levels between varieties.

In terms of sugar contents present in the inflorescences, 'White Cherie' was statistically different from the others, having the highest percentages of TSS, RS and NRS, with increments of $3.3 ; 2.9 ; 3.4$, respectively (Table 2 ).
This finding may be a consequence of its low dimensions, indicating that the plant prioritized carbohydrate retention over the development of reproductive organs, which explains its lower fresh mass. The present data corroborate those published by Santos et al. (2016), who observed variations in carbohydrate metabolism during flower opening in Lilium pumilum.

Table 2. Total soluble sugar (TSS), reducing sugar (RS) and non-reducing sugar (NRS) contents in inflorescences and leaves of four mini chrysanthemum varieties

\begin{tabular}{|c|c|c|c|}
\hline & Inflorescence & & NRS (\%) \\
\hline Variety & TSS (\%) & RS (\%) & $0.54 \mathrm{~b}$ \\
\hline 'Swifty Light Pink' & $0.64 \mathrm{~b}$ & $0.10 \mathrm{~b}$ & $0.33 \mathrm{~b}$ \\
\hline 'Diablo Time' & $0.38 \mathrm{~b}$ & $0.05 \mathrm{~b}$ & $1.76 \mathrm{a}$ \\
\hline 'White Cherie' & $1.96 \mathrm{a}$ & $0.20 \mathrm{a}$ & $0.70 \mathrm{~b}$ \\
\hline 'Giovanni' & $0.77 \mathrm{~b}$ & $0.06 \mathrm{~b}$ & $\mathbf{N R S}(\mathbf{\%})$ \\
\hline & Leaves & $-0.41 \mathrm{c}$ \\
\hline 'Swifty Light Pink' & TSS (\%) & $\mathbf{R S}(\mathbf{\%})$ & $-0.35 \mathrm{c}$ \\
\hline 'Diablo Time' & $1.15 \mathrm{a}$ & $1.56 \mathrm{a}$ & $-0.26 \mathrm{~b}$ \\
\hline 'White Cherie' & $0.80 \mathrm{~b}$ & $1.16 \mathrm{~b}$ & $-0.16 \mathrm{a}$ \\
\hline
\end{tabular}

Means followed by the same letter do not differ according to the Scott-Knott test at the 5\% probability level.

By contrast, the inflorescence of 'Diablo Time' showed the largest dimensions and low sugar values, which may indicate that its carbohydrate had been degraded, probably due to a high respiratory rate, since sugars act in the maintenance of fundamental processes to prolong the shelf life of flowers, improving water balance by regulating transpiration and by increasing water absorption (Nowak and Rudnicki, 1990).

As for the leaves characteristics, diameter and height were $25.39 \%$ and $23.83 \%$ greater in 'White Cherie' and 'Giovanni' compared to 'Swifty Light Pink' and 'Diablo Time', respectively. In terms of leaf fresh mass, a statistical difference was found in 'Giovanni', whose value was 1.55 times higher than that measured in the other varieties (Table 1). A similar result was observed in the inflorescences, indicating an optimum water balance in the plant and in the cut flower.

The visual aspect of the leaves is also considered as a quality criterion, mainly in potted plants. The greenish characteristic is due to the presence of chlorophyll, which decline throughout the senescence process, occurring concurrently with the production and/or revelation of caronenoids, which provide the yellowish color of the leaves. In the present study, it was observed that the chlorophyll content was highest in varieties 'White Cherie' and 'Giovanni', whose values were approximately 23.83\% higher than that found in 'Swifty Light Pink' (Table 1).

Regarding the quantification of sugars in the leaves (Table 2), 'Swifty Light Pink' exhibited 2.73 times higher TSS content and 2.68-times higher RS content than variety 'Giovanni', which showed the lowest sugar contents.

The negative value observed for NRS indicates lack of sucrose in those vegetative organs, which is likely because it was degraded and utilized in the development of reproductive organs. It should be stressed that the flowers were on the point of sale; i.e., with $50 \%$ of their flowers open, suggesting that the low sucrose content in the leaves is related to the mobilization of this compound for flower opening, according to the source-drain ratio. Therefore, maintaining the inflorescences open implies high energy requirements and elevated metabolism, which, in turn, requires an increase in respiratory rates and a given concentration of substrate for obtaining energy (DiasTagliacozzo et al., 2005).

An inversely proportional relationship between fresh mass and sugars was detected both in the inflorescence and in the leaves. This phenomenon is explained by the allocation of carbohydrates for the vegetative or reproductive growth organs, as occurred in the epicotyls and cotyledons of Schizolobium parahyba (Vell.) S.F. Blake (Weidlich et 
al., 2010). It is worth emphasizing that the source (leaf): drain (flowers) ratio may be altered by an increase or reduction in source strength (photosynthetic rate) or drain strength (assimilate requirement), which interferes with the balance between the growth of vegetative and generative compartments in the plant (Duarte et al., 2010).

These data of vegetative and reproductive characteristics can contribute to the production of hydrides that contain an adequate amount of pigments and carbohydrates, in order to guarantee color and adequate shelf life, as with the advancement of development there is a reduction of these molecules.

\section{Conclusions}

Morphophysiological differences were observed between the mini chrysanthemums varieties. The obtained data are basic information for genetic improvement programs, being able to contribute to innovations in appearance and increase the durability of ornamental plants.

\section{Author Contribution}

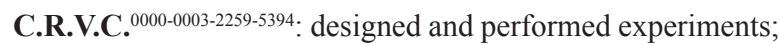
analyzed the data and wrote the article, M.N.S.S..$^{000-0002-5895-112 x}$ : analyzed the data and wrote the article, A.M.M. ${ }^{0000-0002-6028-1989}$ : conceived the project, revised and complemented the wording.

\section{Acknowledgements}

To the National Council for Scientific and Technological Development (CNPq), and Coordination for the Improvement of Higher Education Personnel (CAPES) for their financial support.

\section{References}

ADACHI, M.; KAWABATA, S.; SAKIYAMA, R. Effects of temperature and stem length on changes in carbohydrate content in summer-grown cut chrysanthemums during development and senescence. Postharvest Biology and Technology, v.20, n.1, p.63-70, 2000. DOI: https://doi. org/10.1016/S0925-5214(00)00106-X.

BARBOSA, J.G.; GROSSI,A.S.; BORÉM,A. Crisântemo: do plantio à colheita. Viçosa: Editora UFV, 2019. 135p.

BOUTIGNY, A.; DOHIN, N.; PORNIN, D.; ROLLAND, M. Overview and detectability of the genetic modifications in ornamental plants. Horticulture Research, v.7, n.11, p.1-12, 2020. DOI: https://doi.org/10.1038/s41438-0190232-5.

BRAINER, M.S.C.P. Quando nem tudo são flores, a floricultura pode ser uma alternativa. Caderno Setorial, v.3, n.42, p.1-17, 2018.
BROUILLARD, R. Flavonoids and flower colour. In: HARBORNE, J.B. (eds). The Flavonoids. Boston: Springer, 1988. p.525-538.

DIAS-TAGLIACOZZO, G.M.; FINGER, F.L.; BARBOSA, J.G. Fisiologia pós-colheita de flores de corte. Revista Brasileira de Horticultura Ornamentais, v.11, n.2, p.8999, 2005. DOI: https://doi.org/10.14295/rbho.v11i2.48.

DUARTE, T.S.; PEIL, R.M.N. Relações fonte: dreno e crescimento vegetativo do meloeiro. Horticultura Brasileira, v.28, n.3, p.271-276, 2010. DOI: https://doi. org/10.1590/S0102-05362010000300005.

DUBOIS, M.; GILLES, K.A.; HAMILTON, J.K.; REBERS, P.A.; SMITH, F. Colorimetric method for determination of sugars and related substances. Analytical Chemistry, v.28, n.3, p.350-356, 1956. DOI: https://doi. org/10.1021/ac60111a017.

FERREIRA, D.F. Sisvar: a computer statistical analysis system. Ciência e Agrotecnologia, v.35, n.6, p.10391042, 2011. DOI: https://doi.org/10.1590/S141370542011000600001 .

FULEKI, T.; FRANCIS, F.J. Quantitative methods for anthocyanins. 1. Extraction and determination of total anthocyanins in cranberries. Journal of Food Science, v.33, n.1, p.72-77, 1968. DOI: https://doi. org/10.1111/j.1365-2621.1968.tb00887.x.

IBRAFLOR. Instituto Brasileiro de Floricultura. 2019. Available at: <http://www.ibraflor.com/>. Acessed on: March $11^{\text {th }}, 2019$.

LOPES, T.; XAVIER, M.; QUADRI, M.G.; QUADRI, M. Antocianinas: uma breve revisão das características estruturais e da estabilidade. Revista Brasileira Agrociência, v.13, n.3, p.291-297, 2007. DOI: https://doi. org/10.18539/CAST.V13I3.1375.

NELSON, N. A Photometric adaptation of the Somogyi method for the determination of glucose. Journal of Biological Chemistry, v.153, p.375-380, 1944.

NOWAK, J.; RUDNICKI, R.M. Postharvest handling and storage of cut flowers, florist greens and potted plant. Portland: Timber Press, 1990. 210p.

PARK, C.H.; CHAE, S.C.; PARK, S.; KIM, J.K.; KIM, Y.J.; CHUNG, S.O.; ARASU, M.V.; AL-DHABI, N.A.; PARK, S.U. Anthocyanin and carotenoid contents in different cultivars of Chrysanthemum (Dendranthema grandiflorum Ramat.) flower. Molecules, v.20, n.6, p.11090-11102, 2015. DOI: https://doi.org/10.3390/molecules200611090. 
SANTOS, M.N.S.; MAPELI, A.M.; TOLENTINO, M.M. Carbohydrate metabolism in floral structures of Lilium pumilum in different development stages. Ciência Rural, v.46, n.7, p.1142-1144, 2016. DOI: https://doi. org/10.1590/0103-8478cr20140956.

SATOH, S.; WATANABE, M.; CHISAKA, K.; NARUMI, T. Suppressed leaf senescence in chrysanthemum transformed with a mutated ethylene receptor gene mDGERS1 (etr14). Journal of Plant Biology, v.51, n.6, p.424-427, 2008. DOI: https://doi.org/10.1007/BF03036064.

TAIZ, L.; ZEIGER, E.; MÜLLER, I.M.; MURPHY, A. Fisiologia e Desenvolvimento Vegetal, 6ed. Porto Alegre: Editora Artmed, 2017. 858p.

TERRA VIVA. Crisântemo - vaso. Available at: < https:// www.terraviva.agr.br/crisantemo-vaso $>$. Acessed on: April $30^{\text {th }}, 2020$.

VAN DOORN, W.G.; CRUZ, P. Evidence for a woundinginduced xylem occlusion in stems of cut chrysanthemum flowers. Postharvest Biology and Technology, v.19, n.1, p.73-83, 2000. DOI: https://doi.org/10.1016/S09255214(00)00069-7.
VEILING HOLAMBRA. Flores e Plantas ornamentais Padrão de qualidade. Available at: < http://www.veiling. com.br/padrao-qualidade $>$. Acessed on: April 30 ${ }^{\text {th }}, 2020$.

WEIDLICH, E.W.; PESCADOR, R.; UHLMANN, A. Alocação de recursos (carboidratos) no desenvolvimento inicial de plântulas de Schizolobium parahyba (Vell.) S.F. Blake (Fabaceae - Caesalpinioideae). Revista Árvore, v.34, n.4, p.627-635, 2010. DOI: https://doi.org/10.1590/ S0100-67622010000400007.

ZANDONADI, A.S.; MAIA, C.; BARBOSA, J.G.; FINGER, F.L.; GROSSI, J.A. Influence of long day son the production of cut chrysanthemum cultivars. Horticultura Brasileira, v.36, n.1, p.33-39, 2018. DOI: https://doi. org/10.1590/s0102-053620180106. 